\title{
EFEKTIVITAS LEMBAR KEGIATAN SISWA (LKS) MODEL 5E UNTUK MENINGKATKAN PRESTASI BELAJAR SISWA
}

\author{
Muhamad Zikrullah', Wildan², dan Yayuk Andayani ${ }^{3}$ \\ ${ }^{1}$ Mahasiswa Prodi Pendidikan IPA Program Pascasarjana Universitas Mataram \\ 2,3 Dosen Prodi Pendidikan IPA Program Pasca Sarjana Universitas Mataram
}

\begin{abstract}
Abstrak
Latar belakang penelitian ini berdasarkan pada rendahnya prestasi belajar siswa di MAN 1 Mataram. Hal tersebut diketahui berdasarkan prestasi belajar kognitif siswa pada semester 2 tahun pelajaran 2012/2013 dan 2013/2014. Penelitian ini bertujuan untuk mengetahui efektifitas penggunaan lembar kegiatan siswa model 5E dalam pembelajaran kimia materi pokok reaksi reduksioksidasi. Desain penelitian eksperimen menggunakan posttest only design with non-equivalent group dengan 2 kelas sampel, menunjukkan hasil thitung $>t_{\text {tabel }}\left(t_{\text {hitung }}=5,815\right.$ dan $\left.t_{\text {tabel }}=1,672\right)$ pada taraf signifikansi 0,05. Dari hasil penelitian dapat disimpulkan bahwa prestasi belajar siswa yang belajar menggunakan lembar kegiatan siswa (LKS) model 5E lebih tinggi daripada prestasi belajar siswa yang belajar dengan menggunakan lembar kegiatan siswa (LKS) biasa pada materi pokok reaksi reduksi-oksidasi.
\end{abstract}

Kata Kunci : Lembar Kegiatan Siswa, Model 5e, Prestasi Belajar 


\section{PENDAHULUAN}

Berdasarkan studi pendahuluan terhadap hasil kegiatan pembelajaran Kimia di MAN 1 Mataram, diperoleh data prestasi belajar siswa pada materi pokok reaksi reduksi-oksidasi kurang optimal. Hal tersebut dapat diidentifikasi penyebabnya sebagai berikut: (1) Bahan ajar berupa Lembar Kegiatan Siswa (LKS) yang digunakan bukan hasil pengembangan dari guru sekolah tersebut akan tetapi Lembar Kegiatan Siswa (LKS) yang diperoleh dari penerbit yang telah disediakan sehingga terkadang tidak sesuai dengan kebutuhan dan kondisi siswa. (2) Dalam penerapan penggunaan Lembar Kegiatan Siswa (LKS) yang diperoleh dari penerbit, model pembelajaran yang digunakan dalam proses pembelajaran tidak terintegrasi dengan Lembar Kegiatan Siswa (LKS) yang digunakan, (3) Faktor kesiapan mental siswa untuk menerima pelajaran kurang diperhatikan, disebabkan oleh beberapa faktor yaitu: susunan kegiatan pada lembar kegiatan siswa (LKS) tidak terintegrasi dengan model pembelajaran yang di rancang oleh guru dan konten lembar kegiatan siswa (LKS) yang digunakan belum sepenuhnya mengakomodir indikator yang telah dirumuskan oleh guru. (4) Lembar kegiatan siswa (LKS) yang digunakan belum menyentuh keterkaitan antara materi terutama materi redoks dengan konteks dalam kehidupan seharihari siswa, hal yang demikian membuat siswa merasa kurang tertarik mengikuti proses pembelajaran. (5) Petunjuk praktikum materi reaksi redoks pada Lembar Kegiatan Siswa (LKS) memuat langkah-langkah yang sulit untuk dilakukan oleh siswa, sehingga guru jarang memberikan metode praktikum pada materi reaksi redoks, (6) Petunjuk pada Lembar Kegiatan Siswa (LKS) kurang mampu mengarahkan siswa untuk aktif dalam kegiatan diskusi kelas maupun diskusi kelompok serta memfasilitasi siswa supaya aktif belajar secara mandiri di luar jam sekolah, Yamin dalam Oka (2010) menjelaskan bahwa kegiatan belajar mandiri memiliki pengaruh yang signifikan terhadap peningkatan prestasi belajar siswa, (6) Soal-soal latihan dan penugasan yang ada dalam Lembar Kegiatan Siswa (LKS) yang digunakan secara umum pada materi redoks kurang beragam sehingga siswa kurang terlatih 
untuk menyelesaikan permasalahan-permasalahan yang lebih kompleks.

Salah satu upaya yang sedang dilakukan pemerintah dalam meningkatkan mutu proses pembelajaran adalah pembelajaran yang berpusat pada siswa (student centered) melalui kegiatan inkuiri (Permendiknas, 2013). Salah satu model dengan kegiatan inkuiri adalah model siklus belajar (learning cycle) 5 tahap (Bass, et al, 2009). Model pembelajaran learning cycle (siklus belajar) 5E ini dipilih karena memberikan kesempatan yang lebih luas kepada siswa untuk membangun konsep dari materi yang dipelajari kemudian menggunakan konsep tersebut untuk memecahkan masalah yang lebih kompleks. Siswa lebih dilibatkan secara aktif dalam proses pembelajaran, meningkatkan motivasi belajar dan pembelajaran menjadi lebih bermakna (Bass, et al, 2009). Dasna (2005) menyatakan bahwa dalam model siklus belajar 5E siswa mengembangkan pemahamannya terhadap suatu konsep dengan kegiatan mencoba (hand-on activities) sebelum diperkenalkan dengan kata-kata melalui diskusi sehingga proses pembelajaran menjadi lebih bermakna.

Berdasarkan uraian di atas, tujuan dari penelitian ini adalah untuk mengetahui efektifitas lembar kegiatan siswa (LKS) model 5E dalam meningkatkan prestasi belajar siswa mata pelajaran kimia materi pokok reaksi reduksi-oksidasi.

\section{METODE}

Desain penelitian yang digunakan berupa Post-test Only Design With non Equivalent Group (Sugiyono, 2011).

\section{Tabel 1}

Desain Penelitian Post-test Only Design With Non-Equivalent Group

\begin{tabular}{|l|c|c|}
\hline Kelas & Perlakuan & Post-test \\
\hline Eksperimen & $X_{1}$ & $O_{e}$ \\
\hline Kontrol & $X_{2}$ & $O_{k}$ \\
\hline
\end{tabular}

(Sugiyono, 2011)

248 BIOTA: Jurnal Tadris IPA Biologi FITK IAIN Mataram 
Keterangan:

$\mathrm{O}_{\mathrm{e}} \quad$ : pemberian post-test pada kelas eksperimen

$\mathrm{O}_{\mathrm{k}} \quad$ : pemberian post-test pada kelas control

$\mathrm{X}_{1}$ : perlakuan pada kelas eksperimen menggunakan LKS-5E

$\mathrm{X}_{2}$ : perlakuan pada kelas kontrol menggunakan LKS biasa

Sampel penelitian merupakan kelas-kelas dalam populasi yang memiliki karakteristik yang sama, dalam hal ini kelas $\mathrm{X}_{1}, \mathrm{X}_{2}$, dan $\mathrm{X}_{3}$. Sampel yang digunakan adalah dua dari tiga kelas yang tersedia, masing-masing kelas terdiri dari 39 siswa. Subjek uji coba terbatas dalam penelitian ini adalah siswa sekolah menengah atas kelas XI IPA Semester II dan guru kimia MAN 1 Mataram. Untuk uji coba terbatas subjek terdiri dari 6 orang siswa yang tersebar di kelas XI IPA 1, XI IPA 2, dan XI IPA 3 (berkemampuan tinggi, sedang, rendah), sedangkan untuk uji coba lapangan subjek terdiri 2 kelas yakni kelas $\mathrm{X}_{2}$ sebagai kelas eksperimen dan kelas $\mathrm{X}_{3}$ sebagai kelas kontrol.

Penentuan sampel penelitian yang peneliti tempuh berdasarkan intact group (Aprianti, 2011) yaitu data kemampuan awal kimia siswa berupa hasil belajar kimia siswa semester satu (nilai rapor). Pengambilan sampel secara intact group dilakukan karena subyek penelitian yang akan diberikan perlakuan telah terbentuk secara alami dalam satu kelompok belajar yang utuh (Tim Puslitjakov, 2008).

Instrumen pengumpulan data yang digunakan dalam penelitian ini terdiri dari intrumen tes kemampuan kognitif, lembar observasi keterlaksanaan pembelajaran dan lembar respon siswa. Angket respon digunakan untuk mengetahui tanggapan peserta didik terhadap penggunaan lembar kegiatan siswa (LKS) model 5E dalam pembelajaran kimia materi pokok reaksi reduksi-oksidasi. Instrumen tes kemapuan kognitif berupa tes tertulis bentuk pilihan ganda untuk memperoleh data hasil belajar siswa setelah melaksanakan pembelajaran. Selanjutnya data hasil belajar dari kedua kelas sampel dianalisis homogenitas dan normalitasnya untuk mengetahui jenis uji hipotesis yang akan digunakan. Selanjutnya untuk mengetahui 
efektivitas lembar kegiatan siswa (LKS) model 5E digunakan Independent Sample T-test.

$$
T_{\text {test }}=\frac{\bar{X}_{1}-\overline{X_{2}}}{\sqrt{\frac{\left(n_{1}-1\right) S_{1}^{2}+\left(n_{2}-1\right) S_{2}^{2}}{n_{1}+n_{2}-2}-\left(\frac{1}{n_{1}}-\frac{1}{n_{2}}\right)}}
$$

Keterangan:

$\overline{X_{1}} \quad=$ Rata-rata sampel 1

$\overline{X_{2}} \quad=$ Rata-rata sampel 2

$\mathrm{S}_{1}{ }^{2}=$ Varians sampel 1

$\mathrm{S}_{2}{ }^{2}=$ Varians sampel 2

$\mathrm{n}_{1} \quad=$ jumlah sampel 1

$\mathrm{n}_{2}=$ Jumlah sampel 2

\section{HASIL DAN PEMBAHASAN}

\section{a) Data Proses Pembelajaran}

Data hasil penilaian keterlaksanaan langkah-langkah pembelajaran oleh observer selama 3 kali pertemuan (3 x 45 menit) disajikan pada Tabel 2 .

\section{Tabel 2}

Hasil Observasi Keterlaksanaan RPP

\begin{tabular}{llccc}
\hline \multicolumn{1}{c}{$\begin{array}{c}\text { Pertemuan } \\
\text { ke }\end{array}$} & \multicolumn{2}{c}{ Kelas Eksperimen } & \multicolumn{2}{c}{ Kelas Kontrol } \\
Rata-rata & Kategori & Rata-rata & Kategori \\
\hline I & 4 & Sangat baik & 4 & Sangat Baik \\
II & 3.9 & Sangat baik & 4 & Sangat Baik \\
III & 4 & Sangat baik & 4 & Sangat Baik \\
\hline Rata-rata & 3,44 & Sangat Baik & 4 & Sangat Baik \\
\hline
\end{tabular}

250 BIOTA: Jurnal Tadris IPA Biologi FITK IAIN Mataram 


\section{b) Data hasil belajar}

Berdasarkan data yang diperoleh, diketahui bahwa perbandingan hasil belajar kimia siswa yang belajar menggunakan Lembar Kegiatan Siswa (LKS) Model 5E dengan siswa yang belajar menggunakan Lembar Kegiatan Siswa (LKS) biasa memiliki perbedaan yang cukup berarti. Indikator perbedaan tersebut dapat dilihat dari nilai rata-rata siswa yang belajar dengan menggunakan Lembar Kegiatan Siswa (LKS) Model 5E dengan Lembar Kegiatan Siswa (LKS) biasa secara berturut-turut adalah 74,22 dan 70,90 dengan standar deviasi 10,22 dan 10,63. Selain itu, ketuntasan klasikal pada kelompok eksperimen juga lebih tinggi dibandingkan dengan tingkat ketuntasan klasikal pada kelompok kontrol dengan angka 72,22 \% untuk kelompok eksperimen dan 53,25 \% untuk kelompok kontrol. Perbandingan hasil belajar siswa pada kelompok kontrol dan eksperimen selengkapnya ditampilkan dalam Tabel 3.

\section{Tabel 3}

Perbandingan Hasil Belajar Siswa.

\begin{tabular}{|l|c|c|}
\hline \multicolumn{1}{|c|}{ Aspek } & $\begin{array}{c}\text { Kelas } \\
\text { Eksperimen }\end{array}$ & Kelas Kontrol \\
\hline $\begin{array}{l}\text { Jumlah Siswa yang } \\
\text { mengikuti tes }\end{array}$ & 36 & 32 \\
\hline Nilai rata-rata & 74.22 & 70.90 \\
\hline Standar Deviasi & 10.22 & 10.63 \\
\hline Nilai terendah & 53 & 51 \\
\hline Nilai tertinggi & 94 & 91 \\
\hline \% Ketuntatasan Klasikal & 72.22 & 53.25 \\
\hline
\end{tabular}

Persentase ketuntasan belajar secara klasikal antara kelas eksperimen dan kelas kontrol dapat disajikan pada gambar 1 . 


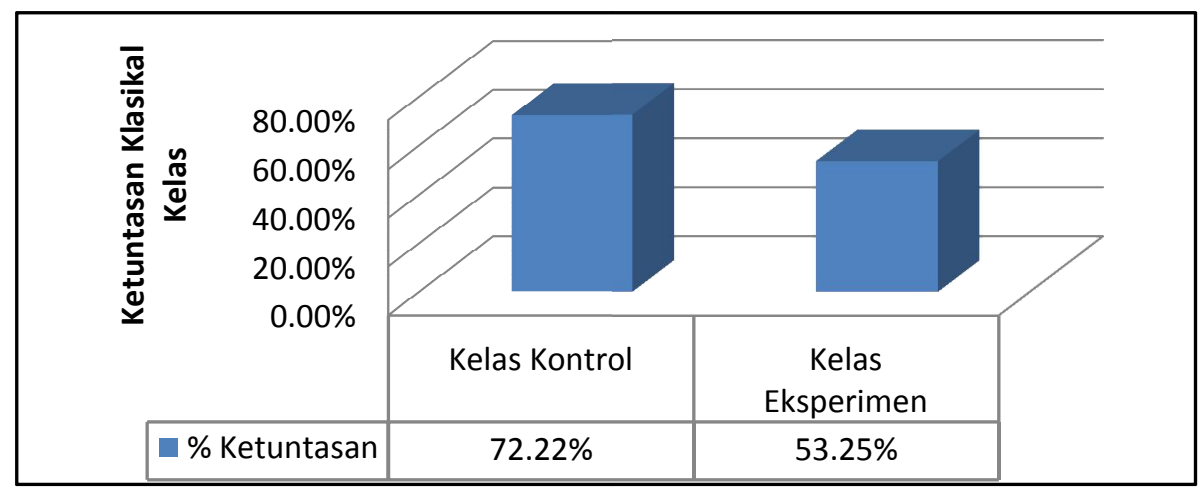

\section{Gambar 1}

Persentase Ketuntasan Belajar

Hasil uji-t terhadap perbedaan dua rerata hasil belajar kimia siswa selengkapnya disajikan dalam Tabel 4.

\section{Tabel 4}

Hasil Uji Hipotesis

\begin{tabular}{ll}
\hline Kriteria pengujian & Hasil pengujian \\
\hline Taraf signifikansi & 0.05 \\
\hline $\mathrm{dk}$ & $\mathrm{n}_{1}+\mathrm{n}_{2}-2=36+32-2=66$ \\
\hline $\mathrm{t}_{\text {hitung }}$ & 5,496 \\
\hline Hasil pengujian & $\mathrm{t}_{\text {hitung }}>\mathrm{t}_{\text {tabel }}$ \\
\hline Kesimpulan & Ho ditolak \\
\hline
\end{tabular}

Data ketuntasan belajar tiap-tiap indikator pada kelas eksperimen dan kelas kontrol dapat disajikan pada Gambar 2.

252 BIOTA: Jurnal Tadris IPA Biologi FITK IAIN Mataram 


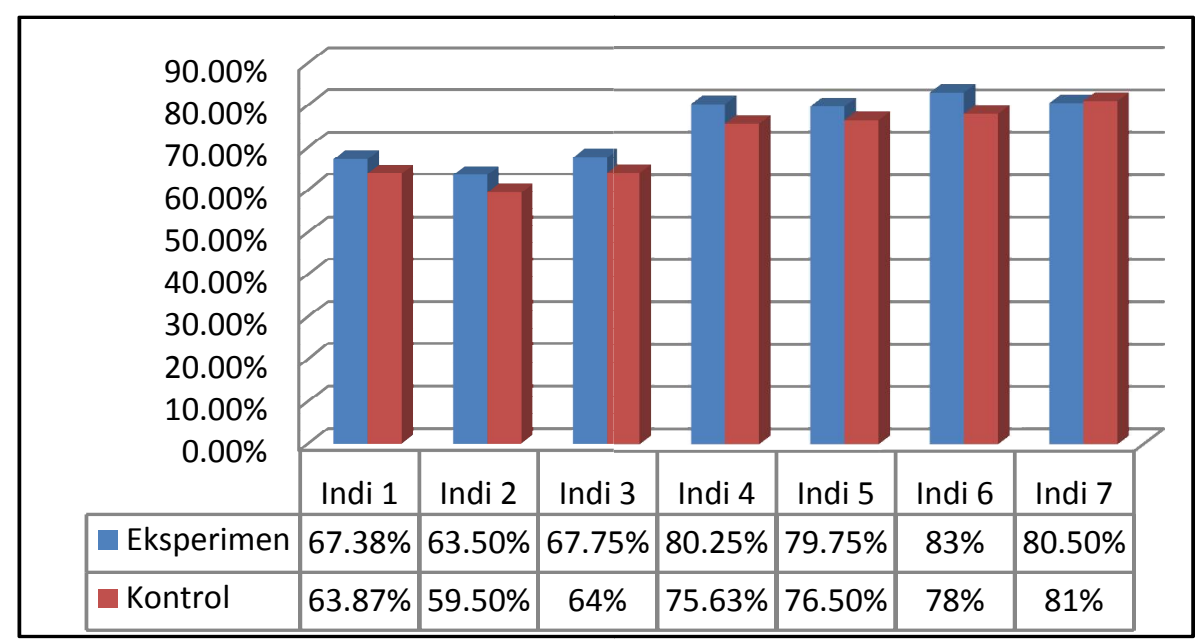

\section{Gambar 2}

Persentase Ketuntasan Klasikal

Data peningkatan ketuntasan belajar klasikal siswa pada materi pokok reaksi reduksi-oksidasi dapat disajikan pada Gambar 3.

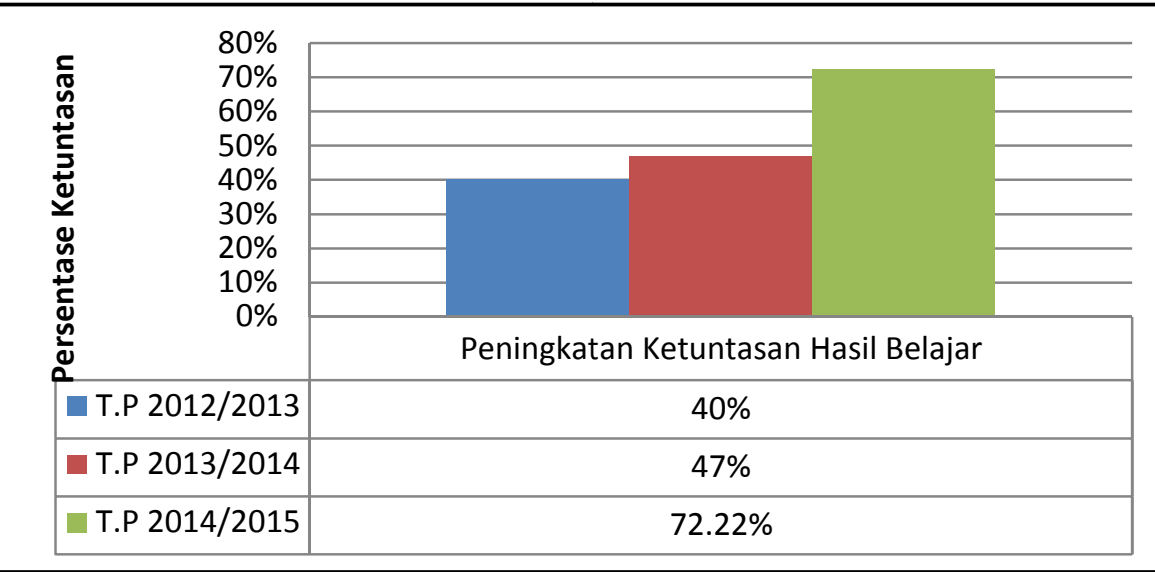

\section{Gambar 3}

Persentase Ketuntasan Klasikal 
Berdasarkan data pada Gambar 2, diperoleh ketuntasan klasikal setiap indikator kompetensi dasar untuk kelas eksperimen lebih tinggi daripada kelas kontrol. Hal tersebut kemungkinan disebabkan karena pada Lembar Kegiatan Siswa (LKS) model 5E berisi tahapan-tahapan pembelajaran yang bersifat konstruktif dalam membangun pemahaman konsep siswa terutama pada materi reaksi reduksi-oksidasi sehingga mempermudah siswa dalam memaknai suatu materi berdasarkan pemahaman yang telah diperoleh dalam kegiatan pembelajaran. Tahap Engage, siswa difasilitasi untuk mempelajari materi berdasarkan fakta sebelum mereka menemukan konsep contohnya menampilkan besi yang berkarat dan apel yang dikupas kulitnya berubah menjadi warna coklat. Tahap ini dapat memancing ketertarikan siswa untuk mempelajari materi reaksi reduksi-oksidasi. Siswa diberikan pertanyaan mengarah apa jenis reaksi dari kedua peristiwa tersebut. Tahap Explore, siswa melakukan kegiatan percobaan sederhana untuk menjawab permasalahan yang disampaikan oleh guru sehingga data-data tersebut digunakan siswa dalam menyusun suatu konsep, misalnya pada peritiwa perkaratan besi siswa mencari informasi dari beberapa sumber informasi kemudian informasi tersebut dikumpulkan dan didiskusikan pada pada tahap selanjutnya. Pada tahap ini siswa dituntun Tahap Explain, siswa melakukan diskusi untuk menganalisis hasil percobaan dan informasi yang telah diperoleh dan menjawab bahan diskuis berdasakan aspek kemampuan kognitif siswa, kemudian mengkomunikasikan hasil diskusi kelompok. Tahap Elaborate, memperluas pemahaman konseptual siswa untuk menggali pengalaman-pengalaman belajar yang baru dan membangun pemahaman yang lebih dalam dan lebih luas serta mengaplikasikan pemahaman yang telah diperoleh pada permasalahan yang lebih luas. Tahap ini siswa diberikan kesempatan untuk berinteraksi dalam kerja kelompok sehingga memungkinkan siswa untuk lebih mudah memahami konsep. Hal ini sesuai dengan penelitian Khaerul Hadi (2013). Tahap Evaluate, mengevaluasi kemajuan siswa dalam mencapai tujuan-tujuan pembelajaran yang telah ditetapkan melalui kegiatan menyimpulkan dan meyajikan hasil pengamatan dalam bentuk laporan

254 BIOTA: Jurnal Tadris IPA Biologi FITK IAIN Mataram 
Faktor lain yang perlu diperhatikan juga bahwa, lembar kegiatan siswa (LKS) model 5E sebagaimana yang telah dipaparkan di atas berisi langkah-langkah yang memuat metodemetode seperti metode praktikum pada tahap Explore, sehingga memungkinkan siswa untuk lebih tertarik memahami materi yang akan dipelajari dan memudahkan siswa dalam memperoleh hasil belajar yang optimal. Hal ini sesuai dengan penelitian Yulianti (2009) yang menyatakan bahwa ada peningkatan yang signifikan terhadap pemahaman siswa ketika metode praktikum diterapkan dalam pembelajaran kimia.

Sebagaimana pemaparan di atas, ilmu kimia dapat dipresentasikan dalam tiga tingkat pemahaman yang saling berkaitan, yaitu: (1) tingkat pemahaman makroskopik, (2) tingkat pemahaman mikroskopik, dan (3) tingkat pemahaman simbolik (Aprianti 2011). Tingkat pemahaman makroskopik diperoleh melalui pengamatan langsung menggunakan indera terhadap suatu fenomena yang terjadi disekitar lingkungan siswa. Dari hasil pengamatan dapat dipresentasikan pada tingkat simbolik dengan menggunakan simbol-simbol sehingga membantu siswa dalam engoptimalkan hasil belajar. Lembar Kegiatan Siswa (LKS) model 5E merangkum ketiga hal tersebut melalui serangkaian kegiatan yaitu tahap Engage membantu siswa memahami materi pada tingkat pemahaman makroskopik, tahap Explore membantu siswa dalam memahami materi pada tingkat mikroskopik dan simbolik sehingga hasil belajar siswa meningkat.

Lembar kegiatan siswa (LKS) model 5E sebagaimana pemaparan di atas berisi 5 tahapan pembelajaran salah satunya adalah tahap Elaborate. Tahap ini merupakan tahapan pemberian masalah-masalah yang lebih dalam dan lebih luas menyangkut materi yang sudah dipelajari siswa untuk diselesaikan berdasarkan konsep dasar yang telah diperoleh. Tahap ini siswa diberikan tugas-tugas terstruktur berupa tugas-tugas yang harus dikerjakan di luar jam pelajaran dengan atau di rumah setiap akhir tatap muka secara berkelompok, sehingga hal ini dapat membantu siswa dalam meningkatkan hasil belajar. Arsyad (2004) mengatakan bahwa sesuatu hal baru jarang sekali dapat dipelajari secara efektif hanya dengan sekali jalan. Agar suatu 
pengetahuan dan keterampilan dapat menjadi bagian kompetensi atau kecakapan intelektual seseorang, haruslah pengetahuan atau keterampilan itu sering diulangi dan dilatih dalam berbagai konteks. Sehingga tahap Eksplore pada lembar kegiatan siswa (LKS) model 5E dapat memfasilitasi siswa untuk melatih pengetahuan siswa dalam berbagai permasalahan dan konteks sehingga hasil belajar siswa dapat optimal. Hal ini sesuai dengan penelitian Khotimah (2010). Yamin dalam Oka (2010) juga menjelaskan bahwa kegiatan belajar mandiri memiliki pengaruh yang signifikan terhadap peningkatan prestasi belajar siswa.

Ketuntasan klasikal pada kelas eksperimen sebesar 72,22 \%. Hal tersebut tidak jauh berbeda dengan hasil penelitian Nurina (2012) yaitu ketuntasan klasikal pada kelas eksperimen sebesar $88,09 \%$.

\section{PENUTUP}

\section{Kesimpulan}

Berdasarkan hasil penelitian eksperimen yang telah dilakukan dapat disimpulkan bahwa lembar kegiatan siswa (LKS) model 5E efektif digunakan untuk meningkatkan prestasi belajar siswa pada materi pokok reaksi reduksi-oksidasi mata pelajaran kimia.

\section{DAFTAR PUSTAKA}

Aprianti. 2011. Pengembangan Modul Pembelajaran Larutan Asam Basa Berbasis Pendekatan MMS dan Implementasinya Dalam Pembelajaran. Tesis tidak diterbitkan. Mataram. Program Studi Magister Pendidikan IPA Unram

Arsyad, Azhar. 2004. Media Pembelajaran. Jakarta: PT Raja Grafindo Persada.

Bass, J. E Contat, T.L. and Carin, A. A. 2009. Teaching Science as Inquiry. Boston: Pearson.

256 BIOTA: Jurnal Tadris IPA Biologi FITK IAIN Mataram 
Dasna, I.W. 2005. Model Siklus Belajar (Learning Cycle) Kajian Teoritis dan Impelementasinya dalam Pembelajaran Kimia. Malang: Universitas Negeri Malang.

Inaiyah, Z. 2013. Penerapan Pembelajaran Learning Cycle 5E Untuk Meningkatkan Penguasaan Konsep Pada Materi Kalor Siswa Di SMAN 9 Malang. Tesis tidak diterbitkan. Malang. Jurusan Fisika Fakultas Matematika dan IPA Universitas Negeri Malang.

Hadi, K. 2013. Pengaruh Penerapan Model Pembelajaran Kooperatif Tipe NHT Terhadap Prestasi Belajar kimia Materi pokok Ikatan Kimia Siswa Kelas X Semester 1 SMAN 1 Wanasaba Tahun Pelajaran 2012/2013. Skripsi tidak diterbitkan. Mataram. Jurusan Pendidikan Kimia Fakultas Keguruan dan Ilmu Pendidikan Unram.

Khotimah. 2010. Pengaruh Penerapan Model Pembelajaran Learning Cycle Terhadap aktifitas dan perestasi Belajar Siswa Pada pembelajaran kimia di Kelas X SMAN 3 Mataram Tahun pelajaran 2009/2010. Skripsi tidak diterbitkan. Mataram. Jurusan Pendidikan Kimia Fakultas Keguruan dan Ilmu Pendidikan Unram.

Nurina, dkk. 2012. Pengembangan Lembar Kegiatan Siswa (LKS) dengan Model Siklus Belajar 5 E Berbasis Konstruktivistik pada Materi Sistem Sirkulasi Manusia untuk Kelas XI. Jurnal Universitas Negeri Malang.

Oka, AA. 2010. Pengaruh Penerepan Belajar Mandiri pada Materi Ekosistem Terhadap Keterampilan Berpikir Kritis dan Kemampuan Memecahkan Masalah Siswa SMA di Kota Metro. Artikel Pendidikan Biologi Universitas Muhammadiyah Metro Lampung.

Permendiknas RI Nomor 65 Tahun 2013 tentang Standar Proses.

Sugiyono. 2011. Metode Penelitian Pendidikan Pendekatan Kuantitatif, Kualitatif, dan R\&D. Bandung : Alfabeta.

Tim Puslitjaknov, 2008. Metode Penelitian Pengembangan: Pusat Penelitian Kebijakan dan Inovasi Pendidikan. Badan Penelitian dan Pengembangan Departemen Pendidikan Nasional 